\title{
PHENOLOGICAL ANOMALIES AND OTHER CURIOSITIES REGARDING THE NESTING OF BIRDS FROM THE WESTERN HALF OF ROMANIA
}

\author{
Aurelian Leonardo Ilie ${ }^{1, *}$, Mariana Marinescu ${ }^{2}$ \\ 1 “Nicolae Jiga” Theoretical Highschool, Republicii Street, No. 36, Tinca Romania \\ ${ }^{2}$ Teacher Training Department, University of Oradea, Universității Street, No. 1, Oradea, Romania
}

\section{Current Trends in}

Natural Sciences

\begin{abstract}
The paper presents the researches about the phenological anomalies and other curiosities regarding the nesting of birds from the western half of Romania during 1996-2020. These anomalies and curiosities were observed at 36 bird species belonging to 31 genera. The majority of these data are not mentioned in the scientific literature. During the analyzed period the following phenological anomalies and other curiosities were founded: additional clutches at 13 species: premature generation at 1 species, delayed generations at 1 species, copula and mating rituals in the cold season at 2 species, additional number of eggs in a clutch at 5 species, confirmation of additional generations at 2 species, little number of eggs at 1 species, curiosities regarding the location of the nest or its height relative to the ground at 6 species, additional generations (with chicks) at 15 species. If these climatic changes persist or worsen, phenological abnormalities in nesting of birds will be observed in a larger number of species and the phenological categories in which they are included will change.
\end{abstract}

Keywords: anomalies, nesting, phenological, Romania, western.

\section{INTRODUCTION}

The interest regarding the characteristics and particularities of the nesting of birds has been and is often major for both scientists and nature lovers. These anomalies and curiosities have been observed over time, but, most of the times, they have only been observations, sporadic occurrences. Recent climatic changes, consequences of global warming, have led to an accentuation of these anomalies being able to estimate that if these climatic changes will continue or increase, these anomalies can become processes or phenomena common in nature.

In Romania, data about phenological anomalies and curiosities of the nesting of birds have been published sporadically in different articles (Ilie, 2014; 2015; 2016; 2017; 2018; Ilie et al., 2015) or specialized books, but a synthesis paper referring exclusively to this topic has not been published so far, thus being a national premiere.

\section{MATERIALS AND METHODS}

The researches were carried out in different areas of the western half of Romania: Bihor county (the north-western part of Romania), Arad county (the western part of Romania) and Dolj county (the south-western part of Romania) between the years 1996-2020, during January-December. Some of 
these observations were made sporadically, spontaneously, as they were not the strictly objective of these trips. The observations were made with the help of the binoculars 20x50 and 8x25, being supplemented with direct observations. For the determination of the bird species and their eggs different guides were used (Hoeher, 1973; Harrison, 1977; S.O.R., 2017).

\section{RESULTS AND DISCUSSIONS}

During 1996-2020, have been observed phenological anomalies and curiosities of nesting of birds to the following species:

- Ardea cinerea Linnaeus, 1758 - strange nesting location: in a fir at a height of 4-5 meters,inside the village of Tinca(BH), in 2015 , at a great distance from a water source (lake or river). Very rarely does the literature mention the nesting of the species at a great distance from the water (Hoeher, 1973; Munteanu, 2012) and within the villages (Munteanu, 2012). Summer visitor, rarely in winter in Romania.

- Podiceps cristatus Linnaeus, 1758 - one female specimen with two nestlings, Girişu Negru (BH), September 27, 2014. In this case, it is the third annual generation, not mentioned in the literature. Summer visitor, rarely in winter at national level.

- Anas platyrhynchos Linnaeus, 1758 - one female specimen and one nesting, Tinca (BH), Crişul Negru river, March 12, 2017. It is the earliest occurrence of chicks in this species at national level! - one female specimen with five duck buds, Tinca, Crişul Negru river, October 15, 2017; one pair with two mallard duck, Cheşa (BH), Crişul Negru river, November 7, 2019. In these two cases it is the third annual generation not mentioned in the literature. Sedentary species in Romania.

- Aythya nyroca Guldenstadt, 1770 - one female specimen with five duck buds, Cheşa (BH), Crişul Negru river, October 8, 2019 (the second annual generation, not mentioned in the literature). Summer visitor, rarely in winter in Romania.

- Anas acuta Linnaeus, 1758 - one female specimen with two duck buds, Râpa (BH), Crişul Negru river, September 3, 2016 (the second annual generation, not mentioned in the literature). Passage species and winter visitor, rarely summer visitor at national level.

- Anser anser Linnaeus, 1758 - one female specimen with three goselings, Oradea (BH), Crişul Repede river, September 12, 2019. Partial migratory species in Romania.

- Falco tinnunculus Linnaeus, 1758 - a juvenile fresh fly, climbed more on branches and flew weakly from tree to tree, still being fed by parents, Oradea (BH), University Park, July 27, 2017. Literature (Linția, 1954) mentions a rare case of nesting and the appearance of chicks on July, 15 in the Prahovei Valley (Carpathians Mountains, central Romania). It is surprising the presence of freshly flown skins at such a late date, literature (Linția, 1954; Ciochia, 1992) mentioning the cessation of the flight of the juvenil flight until the end of June.

- two juveniles fresh fly, being $15 \mathrm{~cm}$ from the nest, Chişineu Criş (AR), September 19, 2019. In this case it is either a later nesting (which started at the end of June) or it is a replacement clutch (although the literature does not mention it in this species) or maybe even the second clutch (a situation less likely which would constitute a scientific novelty). Partial migratory species in Romania.

- Accipiter gentilis Linnaeus, 1758 - nesting in an oak pit, at a height of about one meter above the ground, Gurbediu forest (BH), May 20, 2013. This phenomenon is a novelty, the scientific literature (Harrison, 1977) indicating the location of the nest on the branches! Also, the height of the nest to the ground is atypical, the literature (Hoeher, 1973) indicating a height to ground of 16 - 22 meters. Sedentary species in Romania. 
- Perdix perdix Linnaeus, 1758 - an isolated egg, on an agricultural land, Râpa (BH), October 20, 2018; a female specimen with four chicks, Tinca (BH), November 2, 2016; an egg on an agricultural land, Belfir (BH), December 13, 2015. In these situations it is the second clutch or the second annual generation not mentioned in the literature. Sedentary species in Romania.

- Coturnix coturnix Linnaeus, 1758 - an egg in a pile of straw on the field, Tinca (BH), January 30, 2014. The egg was unfertilized,showing that the specimen was perhaps the last remaining winter here. Although phenologically it is a summer visitor, some specimens remain in the country under milder winters.

- Phasianus colchicus Linnaeus, 1758 - although the literature mentions only an annual generation, Ilie A.L. observes in Craiova (DJ), Romanescu Park, two generations and in the Bihor county three annual generations, the last one being highlighted in autumn-early winter. Example-a female with five small chicks, Tinca forest (BH), December 9,2015; Hidişel (BH), three chicks, November 5,2015; an isolated egg, Tinca spa (BH), October 5, 2016; two eggs and three chicks, Aleşd (BH), August 25,2019; two eggs on the ground, Tinca (BH), December 8, 2017 (in this case probably it is a delayed generation or even fourth generation!); one female with five chicks, Comlăuş (AR), December 19, 2019. Increasing anthropic pressure and the proliferation of stray dogs and perhaps even jackals have led to the placement of nests in prickly bushes (hawthorn, blackthorn), although the species generally nests on the ground. It uses abandoned magpie nests which it arranges, but unlike the magpie nest, this nest is not covered above, it is just the shape of a cup. This type of nesting is very rare, being mentioned in literature (Harrison, 1977). This nesting was observed by Ilie A.L. at the edge of Gurbediu forest (BH) in 2013, Sititelec (BH), Tinca (BH) in 2015 - 2017, Râpa (BH) in 2020. Sedentary species in Romania.

- Gallinula chloropus Linnaeus, 1758-juveniles at Tinca (BH) near Crişul Negru river during October - December 2014 - 2019; a juvenile, Oradea (BH), near Peța rivulet, November 14, 2019. It confirms the existence of the third permanent annual generation that in the past was considered rare, optional. Summer visitor, rarely in winter in Romania.

- Vanellus vanellus Linnaeus, 1758 - juveniles, Belfir (BH) and Tinca (BH), the end of June - July, during 2013 - 2019. Thus, the second generation becomes certain, compared to the literature that considers it rare (Hoeher, 1973). Summer visitor, rarely in winter in Romania.

- Streptopelia decaocto Frivaldszky, 1838 - attempts to nest in winter: the female sat on the nest for several minutes, Tinca (BH), January 24, 2017; a male sat on the nest, Tinca (BH), January $25-28$, 2017, $t=-6^{0} \mathrm{C}$; a female sat on the nest, Tinca (BH), February $1-5,2017, t=2^{0} \mathrm{C}$, then was killed by a goshawk. The nesting of the species during the winter period was also observed by the ornitologists Dimitrie Radu (1984) and Ilie A.L. (Caraula - DJ, December, 2019) who identified in different areas of Romania even chiks that have resisted the whims of winter. Sedentary species in Romania.

- Columba palumbus Linnaeus, 1758 - four juvenile specimens next to one of the parents, Oradea (BH), near Peța rivulet, September 16, 2019. In this case it is the fourth annual generation not mentioned so far in Romania. The literature (Hoeher, 1973) specifies this generation in September. Surely, this clutch was deposited in the second half of August because the juveniles were freshly flown. Also, the number of eggs in a clutch is generally 2-3 (in this case 4), so it is a scientific novelty, a half-broken egg, dropped from the nest, Oradea (BH), December 13, 2019. The very high temperatures of October - November 2019 (16-28 C) are an explanation of this clutch. Summer visitor, rarely in winter in Romania. 


\section{Current Trends in Natural Sciences}

Vol. 9, Issue 17, pp. 187-193, 2020

https://doi.org/10.47068/ctns.2020.v9i17.022

Current Trends in Natural Sciences (on-line)

ISSN: 2284-953X

Current Trends in Natural Sciences (CD-Rom)

ISSN: 2284-9521

ISSN-L: 2284-9521

ISSN-L: 2284-9521

- Streptopelia turtur Linnaeus, 1758 - a nest in a hawthorn at a height of one meter above the ground, right on the water edge (Râpa - BH, Crişul Negru river, June 2, 2015). Surprisingly, this location of the nest is right on the water edge! Regarding the height of the nest to the ground, the data from literature are reconfirmed: 1-4 meters (Hoeher, 1973). Summer visitor in Romania.

- Columba oenas Linnaeus, 1758 - four freshly flown juveniles, Râpa forest - Chişloc (BH), October 26, 2014. Regarding the number of eggs in a clutch and the number of generations, the observations made on the species Columba palumbus L. are maintained. Summer visitor in Romania.

- Columba livia domestica Linnaeus, 1758 - many situations witch clutches consisting of three eggs, encountered in both domestic and wild, in the period 2012-2019. Generally, the clutch comprises two eggs, rarely one (Hoeher,1973). Sedentary species in Romania.

- Tyto alba Scopoli, 1769 - a partially broken egg, Tinca (BH), September 24, 2017. Probably, this is the second delayed annual clutch or maybe even the third! Hoeher (1973) mentions the second annual clutch during June-August. The egg was found in a bridge near a jackdaw (Corvus monedula Linnaeus, 1758) colony, probably being destroyed by them. Sedentary species in Romania.

- Strix aluco Linnaeus, 1758 - nesting in the clayey shores, sometimes ay reduced height (one meter) compared to the ground. This phenomenon unknowned till today in the literature is due to the absence of the tries with hollow in this area, Caraula (DJ), 2013 (fig. 1, 2). This phenomenon was observed too in Vârvoru de Jos area (DJ), 196-1997. Sedentary species in Romania.

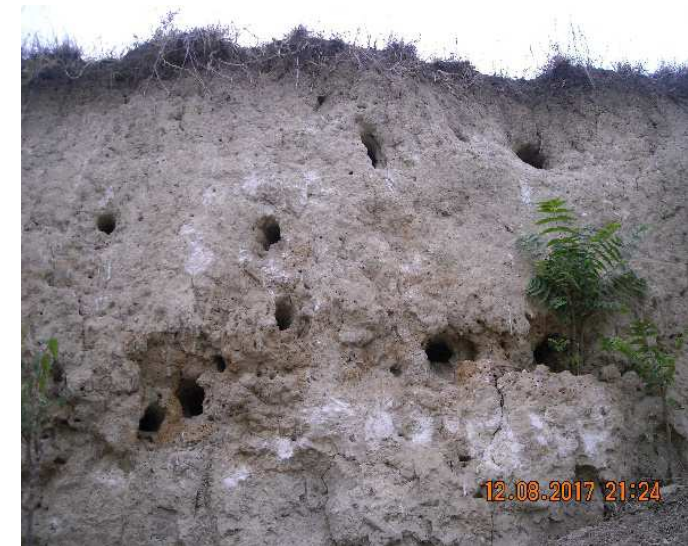

Figure 1. Nests of Strix aluco L. (photo Ilie A.)

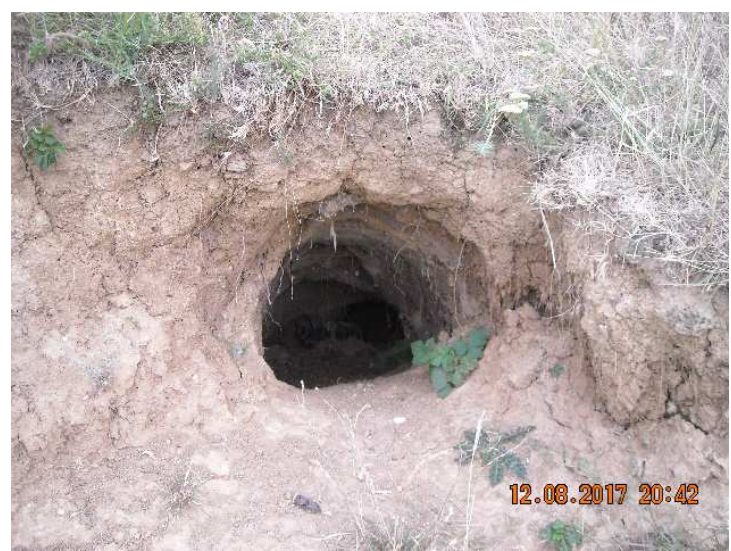

Figure 2. Nest of Strix aluco L. (photo Ilie A.)

- Asio flammeus Pontoppidan, 1763 - one pair with two chicks in a wheat culture, Tinca (BH), September 17, 2016. In this case, this is the second annual generation, thus confirming the literature data (Ciochia, 1992) that affirmed the possibility of this additional generation at national level. Summer visitor, sometimes winter visitor in Romania.

- Merops apiaster Linnaeus, 1758 - many colonies of nests located at relatively large distances from water sources (about a kilometer), Râpa (BH), 2010-2019. Also in Râpa, Ilie A.L. identifies a nest with an upright position (in the ground).The presence of the nests at a great distance from the water sources is inexplicable and there is no disturbance of the nest by humans. Regarding the position of the nests in a vertical position in the ground from the reports of the university professor Dan Munteanu (correspondent member of the Romanian Academy) it turns out that a nest with a similar position of this species was also identified in the Danube Delta. So, this nest positioning is a rarity, an exceptional situation. The choice of this nest position can be partially explained by the absence 
of hills, high banks or other nesting locations. In Râpa area the arrangement of this nest is an enigma, being located a few meters from a hill where there is a colony of nests, so there is place for its arrangement. Summer visitor in Romania.

- Motacilla alba Linnaeus, 1758 - a clutch with six eggs on the ground, Tinca (BH), August 6, 2011; a female feeding a freshly-fledged chicken on a roof, Tinca (BH), August 24, 2019; broken eggs in a nest under an eaves, Tinca (BH), August 21,2019. In all these cases it is the third annual generation, the literature (Hoeher, 1973; Tălpeanu, 1969) indicating the probability of its existence. In the better case it is a very late third generation that has been destroyed because the birds do not leave their eggshells in the nest. The existence of the fourth annual clutch is unlikely in this case. Summer visitor, rarely in winter in Romania.

- Lanius collurio Linnaeus, 1758 - a female with insects in her beak entering a hawthorn bush to feed her chicks, Tinca (BH), August 29,2015. In this case it is the third annual generation, the literature (Ciochia, 1992) mentioning 1-2 annual generations and Harrison (1977) only an annual generation. Summer visitor at national level.

- Oriolus oriolus,Linnaeus, 1758 - a pair with insects in their beaks to feed their chicks, Tinca (BH),August 17, 2013 (probably the third annual generation); a female nesting, Râpa forest (BH),October 8, 2015 (probably the fourth generation!). After a week temperatures dropped a lot and adults left the nest.

The nesting inside the Tinca commune (BH), at a height of two meters, in a plum. The clutch had only one egg, September 28,2017.The surprising of the little height of the nest to the ground, literature (Ciochia, 1992; Hoeher,1973) specifying a high height above the ground of the nest. Also, the very high temperatures of the period 2012-2017 recorded in the autumn favored the emergence of a third or even fourth annual clutch. Summer visitor, rarely in winter in Romania.

- Sturnus vulgaris Linnaeus,1758 -the third annual generation (with flying chicks), Tinca (BH),September 25, 2015; on December 13, Tinca (BH), the fourth annual clutch was dropped, subsequently abandoned due to the low temperatures, the eggs froze and broke. - a whole egg and a broken egg in a bowl, Tinca forest (BH), March 10,2017.In this case, it is probably the earliest known clutch for this species at national level! Sedentary species in Romania.

- Pica pica Linnaeus, 1758 - the third annual generation in 2015: September 25(nest with chicks); October 26 (nest with eggs). At a late date, November 22, 2015, a specimen was found looking for hairs and twigs, probably for the construction of a nest. Ilie A.L. observes that this species builds several nests in the same time, which it uses later for either nesting or for resting, a phenomenon observed in other species: Streptopelia decaocto Friv., Passer montanus L., Passer domesticus L.Sedentary species in Romania.

- Turdus philomelos Brehm, 1831-the fourth annual generation, Râpa forest (BH), September 22, 2015 (nest with chicks that later flew).

- the third annual generation, Cheşa forest (BH), August 28, 2018.Ilie A.L. identifies a nest with only two eggs, the literature (Harrison,1977) indicating three as the minimum number of a clutch, Gurbediu forest (BH),April 14,2017.Summer visitor, rarely in winter in Romania.

- Prunella modularis Linnaeus, 1758 - the third or the fourth annual clutch: a nest with four eggs Râpa forest (BH), October 27, 2015; an other nest with four eggs, Râpa forest (BH), September 22,2015; a nest with three eggs, Râpa forest (BH), December 13, 2015. The literature (Ciochia, 1992) indicates two annual clutches in Romania, the third being considered optional. Due to the high temperatures recorded in the autumn-winter of 2015 the fourth clutch was observed (in 
December), which subsequently froze due to the low temperatures that followed. Passage species or summer visitor in Romania, rarely in winter.

- Phoenicurus ochruros gibraltariensis Gmelin,1789 - the fourth annual clutch: two eggs, Râpa (BH), October 6, 2015; three eggs, Râpa (BH),October 5,2015;one egg, Belfir (BH),October 8,2015.Not all chicks survived, but only those from Tinca flew (November 18, 2015). At national level there were identified three annual generations (Ciochia, 1992; Ilie and Marinescu, 2014). Summer visitor, rarely in winter at national level.

- Troglodytes troglodytes Linnaeus, 1758- the third annual clutch: Râpa (BH), November 14-15, 2015. Literature (Ciochia, 1992) mentions 1-2 annual generations in Romania. Summer visitor, rarely in winter in recent years due to the effects of global warming, the number of specimens observed in the cold season has increased greatly.

- Remiz pendulinus Linnaeus, 1758 - a premature clutch: a nest with three eggs, Gurbediu (BH), January 19, 2014.The explanation for depositing this clutch would be the very high temperatures for this period $\left(15-18^{0} \mathrm{C}\right)$ recorded in the first half of January 2014.Partial migratory species in Romania.

- Parus caeruleus Linnaeus, 1758 - the fourth annual clutch: a nest with two eggs, Tinca (BH), November 23, 2016. Due to the low temperatures this clutch was subsequently abandoned. At national level (Ciochia, 1992) there were identified two annual generations. Ilie A.L. identifies in the period 2012-2019 three safe annual generations in Tinca area (BH). Sedentary species in Romania.

- Parus major Linnaeus, 1758-the third annual generation with chicks that subsequently flew, Tinca (BH), October 6, 2015. European and national literature (Ciochia, 1992; Hoeher, 1973; Harrison,1977) mentions only two annual generations.

- Carduelis chloris Linnaeus, 1758 - an early clutch comprising eight eggs, Husasău de Tinca (BH), February 13, 2017.The large number of eggs (7-8) is rarely encountered in nature and the egg laying period is in April (Ciochia,1992; Harrison,1977). The presence of early clutch can be explained by the favourable weather conditions: $t=11-13^{0} \mathrm{C}$, sunny weather, no snow. Sedentary species in Romania.

- Coccothraustes coccothraustes Linnaeus, 1758 - the fourth annual, partial clutch: a nest with one egg, Tinca forest $(\mathrm{BH})$, November 2, 2018. The existence of this clutch can be explained by the very high temperatures recorded during the period October 25 - November 6, $2018\left(22-26^{0} \mathrm{C}\right)$. European and national literature (Ciochia, 1992, Harrison, 1977) mentions 2-3 annual generations. Sedentary species in Romania.

\section{CONCLUSIONS}

Following the observations regarding the phenological anomalies and other curiosities regarding the nesting of the birds from the western half of Romania during 1996-2020 the following were found: -additional clutches: Perdix perdix L., Coturnix coturnix L., Phasianus colchicus L., Columba palumbus L., Tyto alba Scop., Oriolus oriolus L., Sturnus vulgaris L., Prunella modularis L., Phoenicurus ochruros gibraltariensis Gmel., Troglodytes troglodytes L., Remiz pendulinus L., Parus caeruleus L., Coccothraustes coccothraustes L. -premature generations: Anas platyrhynchos L. -delayed generations: Falco tinnunculus L. -copula and mating rituals in the cold season: Columba livia domestica L., Streptopelia decaocto Friv. 


\section{Current Trends in Natural Sciences}

Vol. 9, Issue 17, pp. 187-193, 2020

https://doi.org/10.47068/ctns.2020.v9i17.022

-additional number of eggs in a clutch: Streptopelia decaocto Friv., Columba oenas L., Columba palumbus L., Phoenicurus ochruros gibraltariensis Gmel., Parus major L.

-confirmation of additional generations: Gallinula chloropus L., Motacilla alba L.

-little number of eggs: Turdus philomelos Brehm.

-curiosities regarding the location of the nest or its height relative to the ground: Phasianus colchicus L., Accipiter gentilis L., Streptopelia turtur L., Merops apiaster L., Ardea cinerea L., Strix aluco L.

-additional generations (with chicks): Podiceps cristatus L., Anas platyrhynchos L., Anas acuta L., Aythya nyroca Guld., Anser anser L., Perdix perdix L., Phasianus colchicus L., Columba palumbus L., Columba livia domestica L., Columba oenas L., Lanius collurio L.,Oriolus oriolus L.,Sturnus vulgaris L., Pica pica L., Turdus philomelos Brehm.

All these phenological anomalies and curiosities have been identified in 36 species of birds, belonging to 31 genera.

\section{REFERENCES}

Ciochia, V., (1992). Păsările clocitoare din România [Brooding birds from Romania], Ed. Ştiințifică, Bucureşti.

Harrison, C., (1977). Nids, oeufs et poussins d'Europe en couleurs [Nests, eggs and chiks of Europe in colours], Ed.Elsevier-Sequoia, Paris-Bruxelles [in French].

Hoeher, C., (1973). Nids et oefs des oiseaux d Europe centrale et occidentale [Nests and eggs of birds from Central and Western Europe], Ed. Delachaux et Niestle, Paris-Lausanne [in French].

Ilie, A.L., (2014). New researches about the insects and vertebrates from Tinca area (Bihor county, Romania), Revista Human education today for tomorrow world, Oradea, No.11 , pp.79-85.

Ilie, A.L., (2015). New researches on the phenology and the behaviour of the birds from Tinca area (Bihor county,Romania), Argesis, Studii şi comunicări- seria Ştiințele Naturii, Piteşti,Tom XXIII, pp.73-77.

Ilie, A.L., Marinescu M., (2015). The protection status of birds from the Caraula area (Dolj county, Romania),Universitatea din Oradea, Fascicula Protectia Mediului,vol.XXIV, pp.25-32.

Ilie, A.L., (2016). Monografie faunistică. Organismele vertebrate din zona Tinca (județul Bihor , România) [Faunal monography. Vertebrates from Tinca area (Bihor county, Romania], Ed. Sitech, Craiova (in Romanian).

Ilie, A.L., (2017). Observații asupra faunei de vertebrate din zona Tinca (județul Bihor, România) în perioada 1 aprilie-1 septembrie 2017 [Observations regarding the vertebrates fauna from Tinca area (Bihor county, Romania) during April 1 - September 1, 2017], Mnemosyne, vol.8, pp.5-9, Botoşani [in Romanian].

Ilie, A.L., (2018). The fauna of vertebrates from Tinca area (Bihor county, Romania) during September1-November 30,2017, Human education today for tomorrow world revue,Oradea,No.15, pp.65-70.

Linţia, D., (1954). Păsările din R.P.R [The birds from Poplar Republic of Romania], Edit.Academiei R.P.R.,Bucureşti (in Romanian).

Munteanu, D., (2012). Conspectul sistematic al avifaunei clocitoare din România [The faunal view of the brooding avifauna in Romania], Ed. Alma Mater, Cluj-Napoca (in Romanian).

S.O.R., (2017). Guide for identification of the birds.Europe and Mediterranean area.The second edition. Printer Trento,Italy,445 pp.(in Romanian).

Tălpeanu, M., (1969). Cuiburi şi ouă [Nests and eggs], Ed.Ştiințifică, Bucureşti. 